\title{
Kekhasan Penokohan Mandeh dalam Novel Limpapeh Karya A.R Rizal (Sebuah Kajian Semiotika)
}

\author{
Riska Shannia ${ }^{1)}$ \\ Universitas Indraprasta PGRI \\ Jalan Nangka No. 58 C/TB. Simatupang, Tanjung Barat, Jakarta Selatan 12530 \\ Apsanti Djokosujatno ${ }^{2)}$ \\ Universitas Indraprasta PGRI \\ Jalan Nangka No. 58 C/TB. Simatupang, Tanjung Barat, Jakarta Selatan 12530 \\ Restoeningroem $^{3)}$ \\ Universitas Indraprasta PGRI \\ Jalan Nangka No. 58 C/TB. Simatupang, Tanjung Barat, Jakarta Selatan 12530 \\ riskashannia@gmail.com
}

\begin{abstract}
Literary works are the result of artistic creations in all aspects of human life. The description of human life in society in certain areas in the novel forms a distinctive presentation. Limpapeh's novel tells of a family laden with Minangkabau customs. This family is led by a Bundo Kanduang called Mandeh. In her life, Mandeh faced many problems related to family and customary traditions. This research will discuss the peculiarities of Mandeh's position in the storyline and the peculiarities of the presentation of the characters in the novel Limpapeh by A.R Rizal. This study uses qualitative research with content analysis methods. The approach used is Todorov's semiotic approach. Todorov's semantic level theory divides the story into three aspects, namely the semantic aspect, the syntactic aspect, and the verbal aspect. This novel is divided into twenty-six episodes. Mandeh always appears in each episode as the center of events. It shows that the main role in the Limpapeh novel is Mandeh. Mandeh's characteristics are more prominent when compared to other characters. These characteristics of Mandeh are summed up through her actions that appear in each episode. This is called a demonstration technique. Mandeh is depicted as someone who holds closely to customs, is wise, loves the family, is a hard worker, full of empathy, and is a conflict reliever. Her figure is an ideal example of her role as Bundo Kanduang. This is in accordance with the novel's title, Limpapeh, which is the main pillar supporting the house.
\end{abstract}

Keywords: Minangkabau, Bundo Kanduang, Characterization, Todorov's Semiotic approach

\begin{abstract}
Abstrak
Karya sastra adalah hasil kreasi artistik yang masuk ke dalam seluruh aspek kehidupan manusia, salah satunya adalah novel. Gambaran kehidupan manusia pada masyarakat di daerah tertentu di dalam novel membentuk sebuah penyajian yang khas. Novel Limpapeh menceritakan sebuah keluarga yang sarat dengan adat dan istiadat Minangkabau. Keluarga ini dipimpin oleh seorang Bundo Kanduang yang dipanggil Mandeh. Dalam kehidupannya, Mandeh banyak menghadapi permasalahan yang berkaitan dengan keluarga dan tradisi adat. Dalam penelitian ini akan dibahas mengenai kekhasan kedudukan Mandeh dalam alur cerita dan kekhasan penyajian tokoh dalam novel Limpapeh karya A.R Rizal. Penelitian ini menggunakan penelitain kualitatif dengan metode analisis isi. Pendekatan yang digunakan adalah pendekatan semiotik Todorov. Teori tiga tataran semantik Todorov membagi cerita ke dalam tiga aspek, yaitu aspek semantik, aspek sintaksis, dan aspek verbal. Novel ini terbagi menjadi dua puluh enam episode. Dari dua puluh enam episode
\end{abstract}

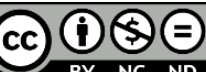

Creative Commons Attribution-NonCommercial-NoDerivatives 4.0 International License 
tersebut, terlihat bahwa Mandeh selalu muncul dalam tiap episode sebagai pusat peristiwa. Itu menunjukan bahwa peran utama dalam novel Limpapeh adalah Mandeh. Sifat-sifat Mandeh terlihat lebih menonjol ketika dibandingkan dengan tokoh-tokoh lainnya. Sifat-sifat Mandeh tersebut disimpulkan melalui tindakan-tindakannya yang dimunculkan pada setiap episode. Hal itu disebut dengan teknik ragaan. Mandeh digambarkan sebagai orang yang memegang erat adat, bijaksana, menyayangi keluarga, pekerja keras, penuh empati dan pereda konflik. Sosoknya merupakan contoh ideal untuk perannya sebagai Bundo Kanduang. Hal ini sesuai dengan judul novel, Limpapeh, yaitu tiang utama menyangga rumah.

Kata Kunci: Minangkabau, Bundo Kanduang, Penokohan, Pendekatan Semiotika Todorov

\section{PENDAHULUAN}

Karya sastra secara umum didefinisikan sebagai sebuah hasil ciptaan tertulis yang disampaikan oleh pengarang untuk tujuan estetik. Dibandingkan dengan tulisan lain, karya sastra memiliki keindahan dan keaslian dalam pengungkapannya. Abrams menjelaskan bahwa adanya hubungan antara alam semesta, pembaca, dan pengarang. Ketiga hal tersebut menjelaskan karya sastra pada prinsipnya terhubung dengan satu hal dan yang lain (Abrams, 1953).

Karya sastra adalah hasil kreasi artistik, yang lahir dari imajinasi, nalar dan perasaan pengarang. Berkat pengalaman hidup, ia memiliki kematangan pikiran dan pengetahuan tentang manusia, serta hidup dan kehidupan. Hal itu memungkinkannya memberikan kesaksian tentang manusia, kehidupan dan lingkungannya sambil menyisipkan pendapat, kritik, serta perasaannya, melalui tokoh dan kisah-kisahnya dalam karya-karya tulisannya (Husen, 1989). Karya sastra masuk ke dalam seluruh aspek kehidupan manusia. Mulai dari hal paling dasar, yaitu diri sendiri, keluarga, masyarakat, adat dan budaya hingga ekonomi dan politik. Beberapa bentuk karya sastra diantaranya puisi, prosa, dan drama.

Gambaran manusia pada masyarakat tertentu di daerah tertentu yang dimunculkan di dalam novel membentuk sebuah penyajian yang khas. Novel yang menekankan latar, ungkapan, dan struktur sosial pada daerah tertentu, memiliki kondisi terpenting yang memberikan efek kepada perangai dan sifat karakter serta cara mereka berpikir, merasa, dan berinteraksi (Abrams, 1999).

Bangsa Indonesia terdiri atas berbagai etnis dan ragam budaya. Sastrawan Indonesia datang dari berbagai etnis banyak menuliskan novel tentang daerah asal dan kebudayaan masing-masing. Ceritanya tidak melulu soal cinta, tapi juga ada yang membahas tentang keluarga, kesenjangan sosial, atau adat istiadat.

Pada abad awal ke-20 dunia kesusastraan Indonesia didominasi oleh pengarang dari Minangkabau. Budaya Minangkabau dengan segala aturan adatnya telah menjadi sumber inspirasi bagi sastrawan yang berasal dari Sumatera Barat dalam seratus tahun ini. Novel Siti Nurbaya karya Marah Roesli (1922) telah menjadi pintu sastra Minangkabau dan juga sastra daerah di kancah kesusastraan Indonesia. Setelah itu muncullah novel-novel lain seperti, Layar Terkembang karya Sutan Takdir Alisyahbana (1937), Tenggelamnya Kapal van der Wijck karya Buya Hamka (1938), Kemarau karya A.A Navis (1967), dan Bako karya Darman Munir (1987).

Pengarang mengangkat potensi budaya etnik atau budaya daerah, yang oleh kritikus sastra sering disebut dengan warna lokal atau warna setempat. Abrams 
menjelaskan bahwa warna lokal adalah representasi terperinci dalam latar sebuah prosa fiksi, di mana dialek, adat, pakaian, dan cara berpikir dan berperasa dikhususkan pada daerah tertentu (Abrams, 1999). Begitu banyak novel yang berlatar daerah yang ditampilkan bersama dengan adat dan istiadatnya. Sebut saja, Laskar Pelangi karya Andera Hirata, yang berlatarkan sebuah desa pesisir di Pulau Belitung, dan Satu Kisah yang Tak Terucap, karya Guntur Alam yang berlatar budaya suku Melayu-Palembang, yang begitu dekat dengan adat istiadat Tionghoa.

Kini, novel Minangkabau maupun daerah lain merupakan bagian dari kesusastraan Indonesia modern. Beberapa novel daerah Sumatera Barat yang diterbitkan setelah tahun 2010 antara lain, Senandung Sabai karya Vera Yuana (2015), Anak Rantau karya Ahmad Fuadi (2017), termasuk Limpapeh karya A.R Rizal (2017) yang akan menjadi objek penelitian ini.

Rizal adalah seorang wartawan harian "Singgalang" yang terbit di wilayah Sumatera Barat. Akibat kejenuhannya menulis berita, Rizal menulis novel Limpapeh ini. Rizal adalah seorang penggiat kelompok diskusi sastra "Yasmin Akbar" di almamaternya, yaitu Universitas Andalas Sumatera Barat. Di saat ia bekerja di ruang sastra di harian "Singgalang", produktivitasnya menulis kreatifnya semakin meningkat, terutama cerita pendek. Tak hanya itu, ia juga menulis novel Maransi, yang menjadi nominasi Dewan Kesenian Jakarta (DKJ) 2019. Buah kerja kerasnya sebagai pengarang muda Ranah Minang layak diperhitungkan.

Novel Limpapeh menceritakan sebuah keluarga yang sarat dengan adat dan istiadat Minangkabau. Keluarga ini dipimpin oleh seorang Bundo Kanduang yang dipanggil Mandeh. Dalam kehidupannya, Mandeh banyak menghadapi permasalahan yang berkaitan dengan keluarga dan tradisi adat.

Limpapeh dalam bahasa Minangkabau, merupakan istilah tentang seorang perempuan Minangkabau yang mendiami rumah gadang, seperti kata adatnya limpapeh rumah nan gadang sumarak anjuang dalam nagari. Limpapeh sendiri memiliki arti tiang utama penyangga rumah. Oleh karena itu, maksudnya adalah perempuan Minangkabau yang mendiami rumah gadang adalah perempuan yang dihormati atau ditinggikan (anjuang adalah bagian yang ditinggikan pada rumah gadang) di desanya. Karena dalam sistem matrilineal perempuan atau kaum ibulah yang mewariskan suku kepada keturunannya kelak.

A.R Rizal sangat bagus dalam menggambarkan sosok Mandeh yang tangguh. Maya Lestari seorang novelis memberikan komentarnya untuk novel ini. Lestari menyebutkan bahwa novel ini berisi kisah sarat emosi yang dituturkan dengan baik, tentang bagaimana ketabahan seorang Mandeh dalam menghadapi masalah di rumah gadangnya. Gaya penulisan dalam Limpapeh dapat menyedot pembaca masuk ke dalam dunia Mandeh dengan segala permasalahan keluarga dan adatnya. Pembaca juga dapat merasakan emosi dan ikut larut dalam setiap konflik yang dihadapi Mandeh.

Berdasarkan latar belakang di atas, penelitian ini bertujuan untuk mengungkapkan kekhasan keududukan Mandeh di dalam alur cerita, dan penyajiannya di dalam novel Limpapeh. 


\section{METODE}

Penelitian ini menggunakan penelitian kualitatif, yaitu penelitian yang bertujuan untuk memahami fenomena yang dialami oleh subjek penelitian secara keseluruhan, dan dengan cara deskripsi dalam bentuk kata-kata dan bahasa, pada suatu konteks khusus yang alamiah dan dengan memanfaatkan berbagai metode alamiah (Moleong, 2014).

Dalam penelitian ini metode yang penulis gunakan untuk menganalisis kekhasan tokoh Mandeh dalam novel Limpapeh karya A.R Rizal adalah metode analisis isi (content analysis) yaitu salah satu metode dalam ilmu sosial yang digunakan untuk mengungkapkan makna yang lebih dalam pada suatu karya sastra. Metode analisis isi ini digunakan untuk menelaah isi dari suatu dokumen atau naskah.

Penelitian ini menggunakan pendekatan semiotika, teori tiga tataran semantik versi Todorov, dan skema aktan. Ferdinand de Saussure adalah Bapak Linguistik Modern berdasarkan pandangan-pandangannya yang dimuat dalam bukunya Course de Linguistique Generale (1915). Semiotik berasal dari kata semeion yang berarti tanda. De Saussure menjelaskan bahwa bahasa adalah sistem tanda, dan tanda merupakan kesatuan antara dua aspek yang tak terpisahkan yaitu, signifant (pedanda) dan signifie (petanda). Penanda adalah aspek formal atau bunyi tanda itu, sedangkan petanda adalah aspek kemaknaan atau konseptual (Teeuw, 1984).

Konsep-konsepnya mengenai linguistik mengilhami para ahli sastra dalam penelitian semiotika struktualisme. Linguistik struktualis berusaha mendeskripsikan suatu bahasa berdasarkan ciri atau sifat khas yang dimiliki bahasa itu. Pada dasarnya De Saussure mengemukakan lima masalah linguistik, yaitu perbedaan langue, langage, dan parole, perbedaan antara penyelidikan diakronis dan sinkronis, hakekat tanda bahasa, perbedaan pragmatik dan sintagmatis, dan perbedaan antara valensi, isi, dan pengertian.

Pertama, De Saussure membedakan apa yang disebut dengan langue, langage, dan parole. Langue adalah keseluruhan sistem tanda yang memiliki fungsi sebagai alat komunikasi verbal antara anggota sebuah masyarakat bahasa yang bersifat abstrak. Langage adalah bahasa secara umum. Sedangkan, parole adalah pemakaian langue secara konkret dalam masyarakat bahasa (Chaer, 2014).

Kedua, perbedaan diakronis dan sinkronis. Telaah bahasa secara diakronis adalah menelaah bahasa sepanjang masa, atau sepanjang zaman bahasa itu digunakan oleh penuturnya. Sedangkan pendekatan sinkronis menelaah bahasa yang dipakai pada suatu kurun waktu tertentu saja. De Saussure menyebutkan bahwa pendekatan sinkronis dapat mempelajari perkembangan bentuk bahasa sampai dapat diperoleh informasi tentang hubungan sistematis antara bentukbentuk bahasa yang sebelumnya, dan perbedaan antara hubungan sistematis dalam berbagai perkembangan bahasa (Kridalaksana, 2005).

Ketiga, hakikat tanda bahasa. Menurut de Saussure, tanda bahasa adalah objek linguistik yang konkret dan integral. Konkret dalam artian berupa kajian terhadap aspek psikis dari tanda bahasa, bukan aspek ujaran, sedangkan integral mengkaji salah satu muka tanda bahasa (signifie atau signifant). Tanda bahasa 
adalah kesatuan yang timbul dari asosiasi citra akustik dengan konsep. Semua tanda bahasa mempunyai dua sifat utama yaitu, arbitrer dan linier. Dalam pandangan de Saussure, arbiter adalah tidak adanya motivasi atau hubungan antara aspek bunyi dalam benda yang ditandainya (Kridalaksana, 2005). Sedangkan linier artinya, setiap tanda bahasa dibentuk oleh rangkaian tanda yang lebih spesifik dan tandatanda itu berada pada satu garis lurus, yang diikat oleh sistem bahasa tertentu (Arnawa, 2008).

Keempat, de Saussure membedakan adanya dua macam hubungan yaitu hubungan sintagmatik dan paradigmatik. Hubungan sintagmatik adalah hubungan antara unsur-unsur yang terdapat dalam suatu tuturan berurutan secara logis. Sedangkan, hubungan paragdimatik adalah hubungan antara unsur sejenis yang terdapat dalam suatu tuturan yang tidak terdapat dalam tuturan yang bersangkutan (Chaer, 2014).

Kelima, perbedaan antara pengertian, isi, dan valensi. Pengertian adalah asosisasi bunyi dengan suatu konsep, yang pada dasarnya sama dengan makna referensial dalam sematik. Isi adalah suatu sistem yang mencakup pengertian dan valensi. Sedangkan, valensi adalah hasil dari pemerian tanda bahasa melalui hubungan sintagmatis dan paragdimatis (Kridalaksana, 2005).

Jadi, dapat disimpulkan bahwa semiotika adalah studi tentang keberadaan tanda-tanda, fungsi tanda dan makna tanda. Keseluruhan sistem tanda merupakan tanda bahasa, yang muncul dari asosiasi citra akustik dan konsep. Tanda bahasa bersifat arbitrer dan linier sehingga memungkinkan untuk menjabarkan hubungan sitagmatis dan paragdimatis dalam setiap tanda bahasa.

Penelitian ini menggunakan pendekan semiotik Todorov. Tzvetan Todorov adalah tokoh stuktualisme Perancis asal Bulgaria. Dalam telaahnya terhadap suatu karya, Todorov membagi cerita ke dalam tiga aspek, yaitu aspek semantik, aspek sintaksis, dan aspek verbal. Melalui tiga tataran tersebut, Todorov menemukan dua unit yang mendasar dari kesatuan struktur, yaitu proposisi dan sekuen.

Todorov membagi cerita ke dalam tiga aspek, yaitu aspek semantik, adalah aspek yang biasanya disebut sebagai isi atau kandungan cerita. Aspek sintaksis adalah pertalian atau hubungan antarperistiwa dalam cerita. Sedangkan aspek verbal adalah keseluruhan penggunaan bahasa untuk menyampaikan isi cerita.

Proposisi atau proposisition adalah bagian pokok suau kalimat yang terdiri dari perbuatan atau aksi yang tidak dapat dijabarkan lagi dan berlaku sebagai dasar kesatuan cerita. Sedangkan sekuen atau sequences adalah satuan hubungan pernyataan yang menyusun sebuah cerita.

Model analisis Todorov memadukan beberapa aspek analisis kebahasaan dalam kerangka pemikiran struktural. Todorov menegaskan bahwa analisisnya ini sedikitnya telah memberikan wujud tata bahasa cerita yang di dalamnya ditemukan beberapa persamaan mendasar antarbahasa dan cerita. Dari cara kerja seperti ini tergambarlah satu pendekatan struktural di mana salah satu pandangannya adalah karya sastra merupakan manifestasi dari sifat asasi bahasa (Nuarca, 2017).

Skema aktan. Skema aktan pertama kali diperkenalkan oleh Algridas Greimas, seorang ahli bahasa dari Lithuania. Greimas memaparkan enam fungsi aktan, dan menjelaskankan relasi antara fungsi-fungsi aktan tersebut. 
Greimas menggambarkankan narasi sebagai sebuah struktur makna (semantic structure) yang memiliki fungsinya sebagai subjek, objek, predikat, dan seterusnya. Setiap kata memiliki relasi dengan kata yang lainnya sehingga membentuk kesatuan yang koheren dan mempunyai makna. Selain itu, karakter dalam narasi menempati posisi dan fungsinya masing-masing. Sebuah narasi dikarakterisasi oleh enam peran yang disebut dengan aktan (Eriyanto, 2013).

Keenam peran tersebut bisa digambarkan sebagai berikut:

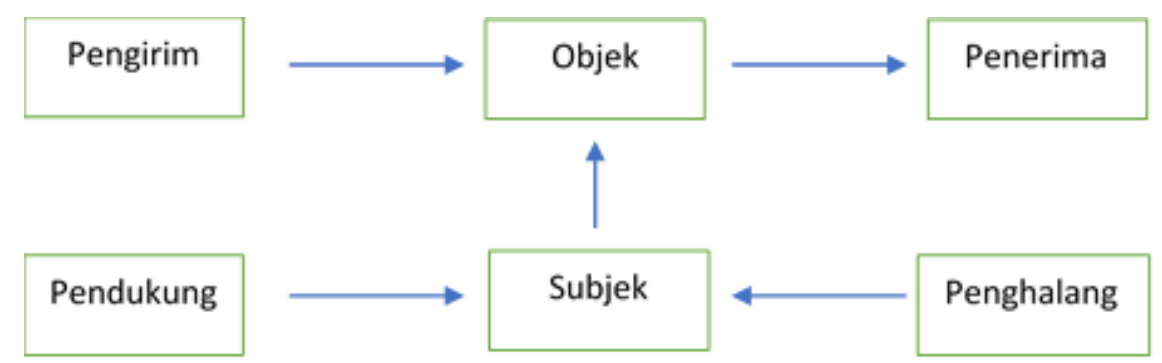

\section{Gambar 1. Skema Aktan}

Greimas melihat adanya keterkaitan antara karakter. Fungsi-fungsi karakter tersebut secara sederhana dibagi menjadi tiga relasi struktural. Pertama, relasi struktural antara subjek dengan objek yang disebut dengan sumbu keinginan (axis of desires). Hubungan ini dapat dilihat dengan jelas dalam teks. Kedua, relasi struktural antara pengirim dan penerima yang disebut sumbu pengiriman (axis of transmission). Pengirim memberikan aturan, nilai, atau perintah supaya objek tercapai. Sementara penerima adalah manfaat setelah objek berhasil dicapai oleh subjek. Ketiga, relasi struktural antara pendukung dan penghambat yang disebut sumbu kekuasaan (axis of power). Pendukung melakukan sesuatu untuk membantu subjek supaya bisa mencapai objek, sedangkan penghalang melakukan sesuatu untuk mencegah subjek mencapai objek (Eriyanto, 2013).

\section{HASIL DAN PEMBAHASAN}

\section{Hasil}

Alur cerita novel berjudul Limpapeh karya A.R Rizal ini akan dibahas pada bagian ini. Untuk itu, akan dibuat episode-episode dalam novel tersebut sesuai dengan urutan penyajiannya. Kemudian, alur cerita secara garis besar akan dibahas dan kedudukan tokoh Mandeh diperjelas melalui skema aktan.

Episode-episode:

1. Niatan Sutan Miang untuk menjual tanah kaum

2. Keinginan Mia untuk diarak di pesta pernikahannya

3. Pian yang ingin memiliki rumah sendiri

4. Gugatan tetangga Mandeh yang serakah

5. Pengeluaran yang sia-sia

6. Pembuangan jimat yang membawa malapetaka 


\section{Diskursus: Jurnal Pendidikan Bahasa Indonesia}

Vol. 3, No. 2, Agustus 2020, pp. 185-196

p-ISSN: 2615-4935

e-ISSN: 2615-4943

7. Masalah hubungan dan pernikahan Lena

8. Perjodohan Nina

9. Kemenakan kesayangan Mandeh

10. Uwak mengunjungi keluarga Sjam

11. Sutan Miang Cari Perkara Lagi

12. Akikah Cucu Mandeh

13. Iri hati Sona kepada Mandeh

14. Meninggalnya Uwak

15. Perbedaan sifat Ikbal dan Idrus

16. Kisah Ikbal

17. Si Junur tetangga Mandeh yang dengki

18. Mandeh Jatuh Sakit

19. Nama Julukan

20. Para Tetangga Mandeh

21. Mandeh Hendak Dipinang Orang

22. Persaingan Saudara Laki-laki Mandeh

23. Perkara Tanah Adat

24. Asal-Usul Nina

25. Sebuah firasat

26. Meninggalnya Mandeh

Novel memiliki dua puluh enam bagian cerita yang tidak diberi judul. Alur cerita yang disajikan melompat-lompat pada setiap episodenya. Oleh karena itu, penulis memberi judul pada tiap episodenya. Dari dua puluh enam episode tersebut, terlihat bahwa Mandeh selalu muncul dalam tiap episode sebagai pusat peristiwa. Itu menunjukan bahwa peran utama dalam novel Limpapeh adalah Mandeh.

Dari rangkaian episode dan penjelasan di atas dapat disimpulkan, kemunculan Mandeh dalam tiap episode menunjukan bahwa Mandeh adalah tokoh utama dalam alur cerita novel Limpapeh. Dalam tiap episode, kekhasan kedudukan Mandeh selalu dimunculkan, ia merupakan kunci penyelesaian tiap masalah. Mandeh dengan perannya sebagai Bundo Kanduang, melaksanakan kewajiban dan tanggung jawabnya dengan sebaik-baiknya. Selain itu, Mandeh menyelesaikan tiap permasalahan dengan caranya sendiri.

Dalam rangkaian episode di atas telah disebutkan bahwa Mandeh merupakan peran utama. Untuk lebih menjelaskan kedudukan Mandeh sebagai subjek dalam cerita maupun urutan naratif, maka akan dibuat skema aktan, yaitu inti cerita dalam novel Limpapeh. 


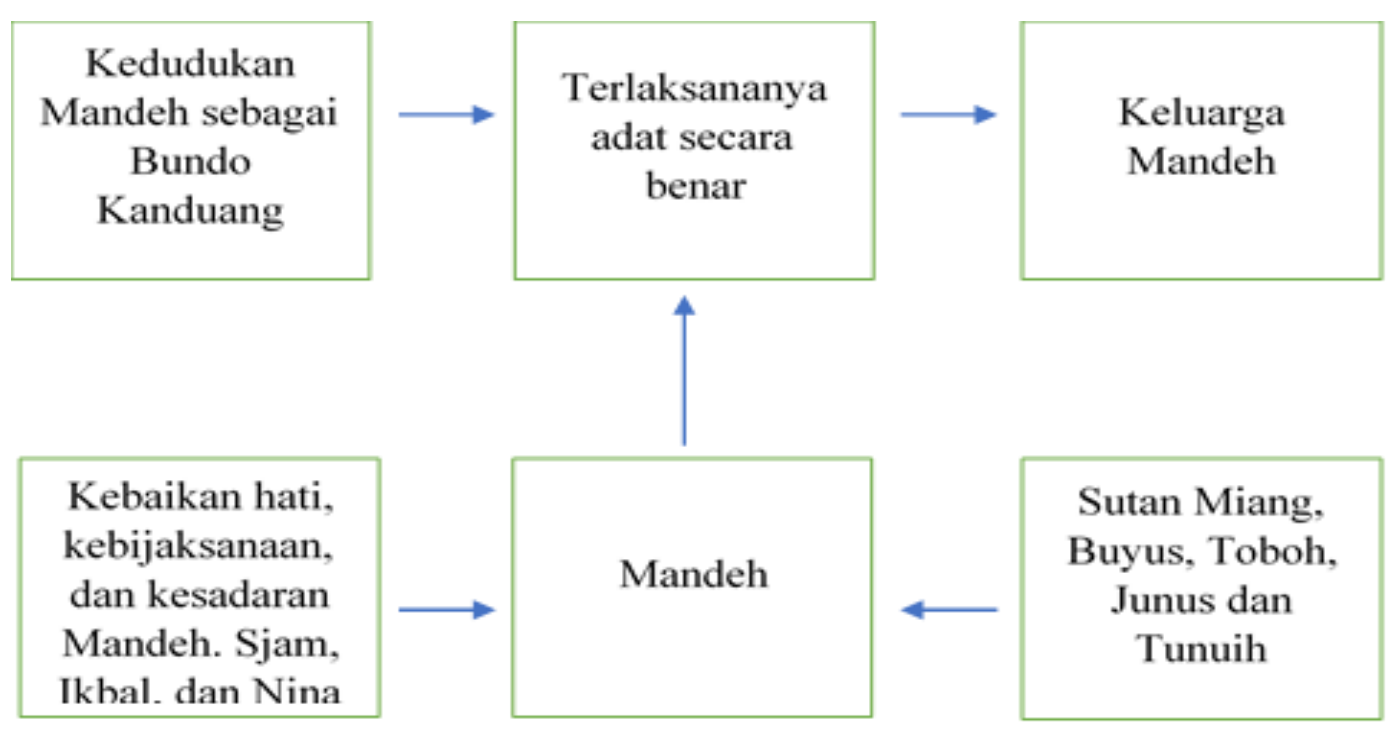

Gambar 2 Skema Aktan dalam Novel

\section{Pembahasan}

Peran Mandeh sebagai Bundo Kanduang dimulai sejak Uwak, ibunya, sudah tua dan mulai sakit-sakitan. Sebelum Uwak meninggal, Uwak memberikan semua harta pusaka dan tanah adat ke tangan Mandeh. Di situlah peran Mandeh yang sesungguhnya sebagai Bundo Kanduang. Aturan-aturan dan kewajibannya sebagai Bundo Kanduang dilaksanakannya dengan baik. Adat dan istiadat pun berjalan dengan semestinya.

Pada novel Limpapeh, terdapat tiga masalah pokok yang diangkat dalam novel tersebut, yaitu masalah keluarga Mandeh, masalah perebutan tanah kaum dan masalah adat. Masalah yang pertama adalah permasalahan keluarga yang muncul pada episode $5,7,8,9,12,14,15,16,19,21$, dan 24. Kedua, masalah perebutan tanah kaum yang muncul pada episode $1,4,11,13,17,22$, dan 23. Pada episode 1, 11, 13, dan 22 adalah masalah perebutan tanah kaum Mandeh oleh saudarasaudaranya, sedangkan pada episode 4, 17, dan 23 adalah masalah perebutan tanah kaum Mandeh oleh tetangga-tetangganya.

Masalah yang ketiga, berkaitan dengan adat istiadat, antara lain masalah pernikahan yang muncul pada episode 2,8 , dan 16, masalah perayaan adat yang muncul pada episode 6 dan 12.

Di dalam tiap episodenya, Mandeh digambarkan dengan kebijaksanaannya dapat menyelesaikan masalah-masalah tersebut. Hal tersebut terus dilakukan oleh Mandeh sampai akhirnya Mandeh meninggal. Pewarisan harta pusaka tinggi dan tanah kaum berhenti di tangan Mandeh, karena ia tidak mau membebani anak perempuannya, Nina.

Mandeh (S) ingin adat istiadat di keluarganya tetap dipegang teguh dan berjuang untuk terlaksananya adat dengan benar (O), tetapi Sutan Miang, Buyus dan Toboh (penghalang) ingin menjual harta tanah kaum. Tetangga Mandeh, Junus 
dan Tunuih (penghalang), juga ingin mengambil tanah kaum miliki Mandeh. Kebaikan hati, kebijaksanaan dan kesadaran Mandeh sebagai perannya sebagai bundo kanduang serta dukungan dari Sjam, Nina dan Ikbal (pendukung) membantu Mandeh untuk dapat menjalankan adat Minangkabau dengan sebaik-baiknya. Kedudukan Mandeh sebagai Bundo Kanduang (pengirim) menyadarkankan Mandeh atas posisinya sebagai kepala rumah tangga yang harus dijalaninya sebaikbaiknya agar terlaksanya adat secara benar $(\mathrm{O})$.

Dapat disimpulkan bahwa Mandeh tampil sebagai tokoh utama dan juga subjek dalam skema aktan, dalam artian yang didorong tanggung jawab sebagai bundo kanduang berusaha mempertahankan tanggung jawab agar terlaksananya adat secara benar.

Tokoh Mandeh sebagai peran utama dapat dilihat melalui kemunculan di tiap episode, sedangkan kekhasa tokoh Mandeh akan terlihat melalui penyajiannya dalam novel.

Di tiap episodenya, penggambaran sosok Mandeh sangat jelas melalui tindakan atau perilakunya. Sedangkan dalam kekhasan gambaran tokoh Mandeh, dapat disimpulkan bahwa Mandeh memiliki sifat-sifat yang positif. Sifat postif ini ditonjolkan lebih banyak dari pada sifat negatifnya. Sosok Mandeh digambarkan sebagai sosok yang teguh dalam memegang adat dan istiadat. Selain itu, Mandeh digambarkan sebagai sosok yang bijaksana, menyayangi keluarga, pekerja keras, penuh empati dan pereda konflik. Mandeh juga merupakan sosok yang sederhana, rendah diri, suka kebersihan, dan bisa menjaga harga diri.

Sifat-sifat Mandeh seperti dua sisi mata uang, yang adakalanya memunculkan sifat negatif. Meskipun begitu, tujuan Mandeh sangat mulia, yaitu Mandeh tidak ingin ada masalah besar dalam keluarga dan lingkungannya. Semua sifat positif maupun negatif Mandeh tersebut tidak selalu berbuah manis. Ironi-ironi tersebut muncul ketika Mandeh dengan tegas memegang erat adat dan istiadatnya mengenai tanah kaum, tetapi saudara laki-lakinya saling berkelahi dan menyebutnya seorang penghalang. Juga ketika Mandeh seharusnya mewarisi harta pusakanya ke anak perempuannya, tetapi Mandeh memilih untuk tidak memberikannya kepada Nina. Hal itu terlihat pada kutipan berikut:

Kalau Sutan Miang, ia penuh syak wasangka kepada Nina. Tanpa alasan, ia tak senang kepada Nina. Sama ketidaksenangannya kepada Mandeh. Ketidaksenangan Miang itu jelas saja apa sebab musababnya. Hatinya marah, karena tak kunjung bisa mendapatkan harta kaum. Mandeh yang penjadi penghalangnya. "Sekarang, kau pula yang ingin berkuasa atas tanah kaum itu," tuding Miang kepada Nina. (episode 23, hal 162)

Juga pada kutipan berikut:

Begitu besar beban di rumah gadang. Mandeh tak akan membaginya kepada Nina. Anak perempuannya itu mesti hidup dengan zamannya. (episode 5, hal 41)

Selain itu, Mandeh sangat menyanyangi keluarganya, tetapi Idrus malah kesal kepada Mandeh karena dianggap pilih kasih dan memilih pergi merantau. 
Dalam perbandingan tokoh Mandeh dengan tokoh-tokoh lainnya, terlihat bahwa kemunculan Mandeh lebih banyak dan ada di semua episode. Sedangkan tokoh-tokoh lain hanya muncul di beberapa episode. Tokoh Nina dan Sjam memiliki kemunculan cukup banyak, tetapi kemunculannya di beberapa episode hanya sekilas saja.

Sifat-sifat Mandeh terlihat lebih menonjol ketika dibandingkan dengan tokoh-tokoh lainnya. Sifat-sifat Mandeh tersebut disimpulkan melalui tindakantindakannya yang dimunculkan pada setiap episode. Hal itu disebut dengan teknik ragaan. Artinya, pengarang tidak secara langsung menyebut sifat-sifat tokoh Mandeh, dan tidak dijelaskan dengan uraian-uraian. Penampilan penokohan berupa ragaan sangat jarang bisa ditemukan dalam novel Indonesia. Novel ini harus berpikir dan menarik kesimpulan sendiri bagi pembaca.

Sifat-sifat positif Mandeh lebih banyak ditampilkan oleh pengarang. Apalagi dengan melihat tindakan-tindakan tokoh lain yang bersifat buruk menambah kualitas dan kuantitas sifat positif Mandeh makin jelas.

Selain penyajian tokoh Mandeh dalam novel Limpapeh yang telah dijelaskan diatas, terdapat pula tokoh-tokoh lain yang dimunculkan. Kemunculan tokoh-tokoh lain tersebut tidak sebanyak kemunculan tokoh Mandeh. Tokoh-tokoh tersebut antara lain, anak-anak Mandeh, yakni Ikbal, Idrus, dan Nina.

Ikbal muncul pada episode $12,15,16,17$, dan 18. Ia merupakan sosok yang dapat diandalkan sebagai anak laki-laki pertama Mandeh. Sifatnya tenang, patuh kepada orang tua, dan sayang keluarga. Idrus, anak kedua Mandeh, muncul pada episode 10, 15, dan 19. Idrus digambarkan terbalik dengan Ikbal, ia merupakan anak pemberontak. Ia pergi dari rumah karena menganggap Mandeh tidak sayang kepadanya dan tidak menyekolahkannya tinggi-tinggi. Anak bungsu Mandeh, Nina, muncul cukup banyak dalam beberapa episode, yakni episode 1,5, 8, 9, 12, 17, 18, $19,20,21,22,23,24$, dan 25 . Nina merupakan sosok yang tegas, cerdas, dan sangat sayang pada ibunya. meskipun kemunculan Nina ada pada banyak episode, tetapi tidak semuanya berupa peristiwa atau tindakan besar.

Tokoh lain yang juga muncul adalah saudara-saudara kandung Mandeh, yaitu Sjam, Sutan Miang, Buyus, Sontong, Ijah, Lena, dan Toboh. Sjam merupakan anak laki-laki pertama dikeluarga Mandeh, yang muncul pada episode 1, 2, 6, 7, 8, $10,11,14,17,20,21$, dan 23. Sosoknya digambarkan sebagai orang yang keras, dan tegas. Ia juga sangat memperhatikan masalah kesehatan dan pendidikan. Ia orang yang cukup kaya dibandingkan dengan saudara-saudaranya yang lain.

Saudara laki-laki yang lain adalah Sutan Miang, Buyus, Sontong dan Toboh. Sutan Miang muncul pada episode 1, 6, 11, 22, 23, dan 26. Sutan Miang digambarkan sebagai orang serakah yang ingin menjual tanah kaum milik keluarganya untuk urusan pribadinya. Buyus muncul pada episode 13 dan 22, ia digambarkan sebagai orang yang takut pada istri dan menginginkan sebagian tanah kaum. Sontong muncul pada episode 9, ia merupakan sosok yang pekerja keras demi istri dan anaknya, Opet dan Laila. Toboh, adik bungsu Mandeh, muncul pada episode 5 dan 22. Ia merupakan orang yang sangat manja, tidak mau berusaha, dan serakah karena ingin pula mengambil sebagian tanah kaum.

Saudara perempuan Mandeh ada dua, yaitu Ijah dan Lena. Ijah muncul pada episode 6, sedangkan Lena muncul pada episode 7. Ijah digambarkan sebagai orang 
gila yang dipercaya oleh keluarganya disebabkan oleh kutukan dukun. Sedangkan Lena adalah gadis sekolah kejuruan yang dipaksa menikah karena memiliki pacar, meskipun ia tidak hamil.

Tokoh-tokoh lain dalam keluarganya yang dimunculkan adalah Pian, Uwak, Mia, Suti, dan Fakhri. Pian adalah suami Mandeh yang muncul pada episode 3, 5, 16 dan 24. Pian merupakan sosok yang bertanggung jawab dan sangat sayang pada keluarganya. Sedangkan Uwak, ibu Mandeh, muncul pada episode 10 dan 14. Uwak adalah sosok pekerja keras, tetapi ia mudah tersinggung. Dulu Uwak adalah orang terpandang yang harta pusaka dan tanah kaumnya sangat banyak, namun lama-lama ia jatuh miskin.

Mia adalah anak Sjam, yang muncul pada episode 2. Ia adalah anak manja, senang diperhatikan, dan senang kemewahan. Selain itu, ada Suti dan Fakhri, yang merupakan menantu Mandeh. Suti muncul pada episode

Suti dan Fakhri adalah menantu Mandeh. Suti adalah istri Ikbal, muncul pada episode 12 dan 16. Ia adalah orang yang sabar. Sedangkan Fakhri adalah suami Nina, yang muncul pada episode 8. Ia adalah orang yang taat agama, rajin, dan pekerja keras.

Selain itu, juga ada tokoh-tokoh lain, yaitu para tetangganya. Tokoh-tokoh tersebut adalah Tunuih, Junur, Eti, dan Zumarni. Tunuih muncul pada episode 4 dan 23. Ia adalah sosok yang serakah, tidak tahu balas budi, dan tamak. Ia menggugat sebagian besar tanah di kampungnya, padahal itu bukan tanah miliknya. Junur dan Eti adalah ibu dan anak, yang muncul pada episode 17, 19, 20, dan 23. Keduanya memiliki sifat yang sama, yaitu serakah dan tidak tahu diri. Selian itu, tokoh Zumarni yang muncul pada episode 8,17 , dan 20. Zumarni adalah orang yang polos tetapi galak. Ia sering mengunjungi Mandeh untuk bergunjing, dan ia juga sering berkelahi dengan Eti.

Dalam novel Limpapeh, Mandeh merupakan role model yang sempurna sebagai Bundo Kanduang. Ia selalu berusaha menjadi perempuan Minangkabau sejati, pemimpin, sekaligus sebagai istri dan ibu seutuhnya. Maka, gambaran tokoh Mandeh sesuai dengan judul novel, Limpapeh, yang berarti tiang utama penyangga rumah.

\section{SIMPULAN}

Limpapeh karya A.R Rizal adalah sebuah novel daerah yang berasal dari Sumatera Barat yang mengangkat kisah seorang perempuan Minangkabau yang dipanggil Mandeh yang memiliki peran sebagai Bundo Kanduang.

Simpulan yang didapat dari penelitian ini adalah kedudukan tokoh Mandeh dalam alur cerita dan rangkaian peristiwa, sangat dominan, dan selalu muncul dalam tiap episode, jauh lebih banyak dibandingkan dengan tokoh lainnya dalam novel tersebut. Tokoh Mandeh jelas merupakan tokoh utama dalam novel Limpapeh karya A.R Rizal. Dalam tiap episode, Mandeh dihadapkan dengan masalah, tetapi di situ ia memegang peran utama penyelesai masalah.

Sifat tokoh Mandeh disajikan oleh pengarang melalui tindakan atau perilakunya, cara penyajian tersebut disebut dengan teknik ragaan. Sifat positifnya 
lebih ditonjolkan dibandingkan dengan sifat negatifnya. Mandeh digambarkan sebagai orang yang memegang erat adat, bijaksana, menyayangi keluarga, pekerja keras, penuh empati dan pereda konflik. Selain itu, Mandeh merupakan sosok yang sederhana, rendah diri, suka kebersihan, dan bisa menjaga harga diri. Meskipun begitu, sifat-sifat Mandeh bagai dua sisi mata uang, salah satunya Mandeh sangat erat memegang adat, tetapi ia tidak berusaha untuk menurunkan penerus penjaga adat. Sifat-sifat tersebut sangat menonjol di antara anggota keluarganya yang lain. Sosoknya merupakan contoh ideal untuk perannya sebagai Bundo Kanduang. Hal ini sesuai dengan judul novel, Limpapeh, yaitu tiang utama menyangga rumah.

\section{DAFTAR PUSTAKA}

Abrams, M. H. (1953). The mirror and the lamp. New York: Oxford University Press.

Abrams, M. H. (1999). A glossary of literary terms. Massachusetts: Heinle \& Heinle.

Arnawa, N. (2008). Wawasan linguistik dan pengajaran bahasa. Denpasar: Pelawa Sari.

Chaer, A. (2014). Linguistik umum. Jakarta: PT. Rineka Cipta.

Eriyanto. (2013). Analisis naratif: Dasar-dasar dan penerapannya dalam analisis teks berita media. Jakarta: Kencana.

Husen, I. S. (1989). Pemahaman sri sumarah karya umar kayam dalam pelajaran pengkajian teks sastra. Konstelasi Sastra. Depok: Devisi Penerbitan HISKI Pusat Universitas Indonesia.

Kridalaksana, H. (2005). Mongin-Ferdinand de Saussure: Peletak dasar struktualisme dan linguistik modern. Jakarta: Yayasan Pustaka Obor Indonesia.

Moleong, L. J. (2014). Metodologi penelitian kualitatif. Bandung: PT Remaja Rosdakarya.

Nuarca, I. K. (2017). Struktualisme semiotik dalam ilmu sastra. Denpasar: Univesitas Udayana.

Rizal. A. R. (2017). Limpapeh. Padang: Penerbit Erka.

Teeuw, A. (1984). Sastra dan ilmu sastra. Bandung: PT. Dunia Pustaka Jaya. 